\title{
Operational Forces soldiers' perceptions of attributes and skills for career success
}

\begin{tabular}{|c|c|}
\hline \multicolumn{2}{|c|}{$\begin{array}{l}\text { Authors: } \\
\text { Ishreen Rawoot }{ }^{1} \text { (1) } \\
\text { Adelai van Heerden }{ }^{1} \text { (『) } \\
\text { Laaiqah Parker }^{1}\end{array}$} \\
\hline \multicolumn{2}{|c|}{$\begin{array}{l}\text { Affiliations: } \\
{ }^{1} \text { Behavioural Science } \\
\text { Capability (Technology for } \\
\text { Special Operations), Defence, } \\
\text { Peace, Safety and Security } \\
\text { Unit, Council for Scientific } \\
\text { and Industrial Research, } \\
\text { South Africa }\end{array}$} \\
\hline \multicolumn{2}{|c|}{$\begin{array}{l}\text { Corresponding author: } \\
\text { Ishreen Rawoot, } \\
\text { irawoot@csir.co.za }\end{array}$} \\
\hline \multicolumn{2}{|c|}{$\begin{array}{l}\text { Dates: } \\
\text { Received: } 23 \text { Feb. } 2017 \\
\text { Accepted: } 24 \text { Mar. } 2017 \\
\text { Published: } 31 \text { July } 2017\end{array}$} \\
\hline \multicolumn{2}{|c|}{$\begin{array}{l}\text { How to cite this article: } \\
\text { Rawoot, I., Van Heerden, A., } \\
\text { \& Parker, L. (2017). } \\
\text { Operational Forces soldiers' } \\
\text { perceptions of attributes and } \\
\text { skills for career success. SA } \\
\text { Journal of Industrial } \\
\text { Psychology/SA Tydskrif vir } \\
\text { Bedryfsielkunde, 43(0), } \\
\text { a1440. https://doi.org/ } \\
\text { 10.4102/sajip.v43i0.1440 }\end{array}$} \\
\hline \multicolumn{2}{|c|}{$\begin{array}{l}\text { Copyright: } \\
\text { (c) 2017. The Authors. } \\
\text { Licensee: AOSIS. This wC } \\
\text { is licensed under the } \\
\text { Creative Commons } \\
\text { Attribution License. }\end{array}$} \\
\hline \multicolumn{2}{|l|}{ Read online: } \\
\hline 口pra & $\begin{array}{l}\text { Scan this QR } \\
\text { code with your } \\
\text { smart phone or } \\
\text { mobile device } \\
\text { to read online. }\end{array}$ \\
\hline
\end{tabular}

Orientation: A career within the South African Operational Forces is physically, mentally and emotionally challenging. It is a diverse working environment with its own organisational culture and unique challenges.

Research purpose: The aim of the study was to explore the perceptions of Operational Forces soldiers regarding the unique requirements that facilitated their career success.

Motivation for the study: A low percentage of candidates successfully complete the Operational Forces training. The financial implications of training candidates make it important to be able to identify candidates who have the potential to be successful, early on in the process.

Research design, approach and method: Data were collected through a self-administered qualitative survey $(n=98)$. All participants were permanent Operational Forces soldiers with varying ranks and years of experience. The data were thematically analysed in order to identify themes and specific attributes and skills associated with a successful career in the Operational Forces.

Main findings: A number of themes emerged from the data, each of which contributed to our understanding of the research question. The themes included self-concept, personality, interests, cognitive and physical factors.

Practical and managerial implications: The research findings may help to inform decisions about approaches, practices and methodologies of the South African Operational Forces recruitment and selection process. Results also provide military organisations with the key characteristics to consider when identifying candidates with the highest potential for successful careers.

Contribution and value-add: The study extends previous career success research by contributing an additional base of information regarding career success and factors that are perceived to influence it.

\section{Introduction}

The Operational Forces are a force multiplier for the South African National Defence Force (SANDF). They are viewed as a highly exclusive, specialised military unit that operates under the auspices of Joint Operations. 'A career with the Operational Forces is often a lifestyle resolution as much as a career choice' (De Beer \& Van Heerden, 2014, p. 1). Training is demanding and rigorous and includes activities that are aimed at testing candidates' skills and personal attributes. Candidates are exposed to many physical and mental stressors and need to be prepared for deployment anywhere in the world, at any given time (Moorcroft, 2006). This includes physical stressors (sleep deprivation, overuse of muscles, dehydration and injuries), environmental stressors (heat, cold, noise and vibrations) and psychological stressors (sensory overload, time pressures, unpredictability, isolation, anxiety, fear and bereavement) (Christopher, Garber, Butler \& Rauh, 2017; U.S. Department of the Army, 1994).

Recruiting, selecting and successfully training job-fit Operational Forces soldiers is a key challenge not only in South Africa, but also worldwide (Cornum, Matthews \& Seligman, 2011; Gee, 2007; Orvis \& Asch, 2001; The House of Commons, 2008). In South Africa, research is being conducted to improve the recruitment, selection and training success rates of Military Operational Forces (De Beer \& Van Heerden, 2014, 2017; Moorcroft, 2006). A career in this type of specialised military context entails a diverse working environment with its own organisational culture combined with a unique set of challenges. In South Africa, as in the rest of the world, only the highest calibre candidates are selected to undergo specialised military training (De Beer \& Van Heerden, 2014, 
2017); however, attrition rates remain high, with only a small percentage of candidates successfully complete the rigorous selection training (De Beer \& van Heerden, 2014). Training Operational Forces candidates is highly time consuming and costly. To avoid unnecessary wastage of resources as candidates voluntarily or involuntarily retract, it is important to identify candidates who have the potential to complete the training cycle and build successful careers as Operational Forces soldiers, at the earliest possible stages of selection training. It is also vital to be able to identify candidates with a strong interest in staying within the organisation as retention of the context-specific knowledge, skills and attributes embedded within these individuals is crucial (Orb, Eisenhauer \& Wynaden, 2004).

\section{Career success}

Judge, Cable, Boudreau and Bretz (1995, p. 3) define career success as the positive psychological or work-related outcomes or achievements one has accumulated as a result of one's work experiences'. Career success is of concern not only to the individual, but also to the organisations that employ these individuals ( $\mathrm{Ng}$, Eby, Sorensen \& Feldman, 2005). Essentially, an individual's personal success contributes to the success of the organisation as a whole. Researchers in various disciplines have increasingly become interested in identifying and exploring both individual and organisational factors which facilitate employees' career success ( $\mathrm{Ng}$ et al., 2005). In recent years, 'theorists have identified an abundance of career success determinants such as demographics, socioeconomic conditions, cognitive factors, motivational factors and personality characteristics, along with intraorganisational structures, procedures and behaviours' (Harris \& Ogbonna, 2006, p. 43).

Career construction theory was used as the theoretical underpinning of the study. Career construction theory is a career theory that seeks to explain occupational choice and work adjustment. It postulates that for a career to be successful an individual should constantly meet personal as well as interpersonal expectations (Savickas, 2005). This requires them to adjust at various stages of their work life, including effectively preparing, initiating and contributing to their work and dealing with the work demands. These processes enable perceptions of subjective and objective career success (Savickas, 2005). There are both objective and subjective dimensions associated with the concept of career success based on individual, group and societal beliefs, perceptions, expectations and experiences. Arthur, Khapova and Wilderdom (2005) provided a detailed distinction between objective and subjective career success. Objective or extrinsic career success is the external components of career success, which includes observable, measurable and verifiable achievements (compensation/salary and number of promotions). In contrast, subjective or intrinsic career success is the internal components of career success, which includes the individual's personal interpretations, perspective and evaluations of their success in their career (career satisfaction and happiness) (Arthur et al., 2005; Ng et al., 2005).
In their article on career success, $\mathrm{Ng}$ and Feldman (2014) point to a shift away from the traditional objective research focus on career success towards a more subjective focus that incorporate workers' personal experiences and perceptions of their work lives and where personal meaningfulness drive career decisions and success. The authors point to a gap in research that explores the challenges that need to be overcome and the factors that negatively influence individuals' subjective experiences and perceptions of career success in terms of not only the career successes but also the career failures that individuals have had to overcome ( $\mathrm{Ng} \&$ Feldman, 2014). Researchers from diverse disciplines continue to investigate the individual and organisational factors that contribute to or predict employees' attainment of career success; however, most of the studies that explore the factors influencing career success have been conducted internationally with a specific focus on career success in managerial positions (Koekemoer, 2014). South African studies, particularly those related to military recruitment and career success, are limited (Menon \& Kotze, 2007; Smith \& Heinecken, 2014; Visser, 2002).

\section{Military career success}

Although physical ability is a critical component in the career success of an Operational Forces soldier, this is not the sole factor in determining how successful the individual will be (Kelly, Matthews \& Bartone, 2014; Nye et al., 2014). The stress associated with meeting the demands of this challenging environment may cause those who are physically strong but not psychologically fit, to drop out or give up early in the process (Lovering et al., 2015). Worldwide, traditional methods of Operational Forces assessment and selection have until recently focussed almost exclusively on physical fitness (Joint Operations University, 2011). Over the years there has been a considerable shift in the literature, with the move towards the measurement of a combination of cognitive attributes that contribute to the way we learn, remember and solve problems and non-cognitive attributes, which include soft skills, personality traits, non-cognitive abilities, character skills and socio-emotional skills, in addition to physical capabilities (Kautz, Heckman, Diris, Weel \& Borghans, 2014). The concept of the 'whole man' is based on this shift and is increasingly being used by psychologists within the defence environment to evaluate an individual's job-fit profile. In order to assess whether an individual is well fit to a specific job, the 'whole man' or the 'man as a whole' should be considered (Joint Operations University, 2011).

In his book Green Berets, SEALS, and Spetsnaz, Collins (1987) described the essence of all Special Operations Force personnel. He argued that intelligence, physical strength and standard training are not enough and that other factors such as temperament, resourcefulness, ingenuity, pragmatism, patience, self-discipline and dependability should also be considered.

Further research pertaining to the inclusion of 'additional discrete personal attributes' is now being carried out, particularly in the stress management domains of hardiness (Cacioppo et al., 2015), perseverance (Eskreis-Winkler, 
Shulman, Beal \& Duckworth, 2014; Higgins et al., 2015) and decision-making (Grigsby et al., 2012). This is important as the inability of a recruit to manage stress during training will ultimately lead to high levels of attrition among members or to the development of psychological health problems. It is, therefore, of utmost importance to consider multiple facets of an individual rather than just one component or characteristic (Skomorovsky \& Sudom, 2011).

There has been a significant shift in the literature from focussing exclusively on the assessment of physical fitness to towards the assessment of a combination of physical and psychological aspects that make up the individual (Dees, Nestler \& Kewley, 2013). This shift from the physical to the psychological is mainly evident in international literature, particularly in the United States Army with a lack of research available in this area within the African context. A review of the international literature, as presented in Table 1, indicated that there are a number of attributes and skills that are important contributing factors to career success in the defence environment.

Furthermore, two South African studies were identified. Van Dyk and Ditsela (2013) provide an analytical review of the personality factors explaining career success in soldiers. The authors discussed general personality factors such as locus of control, self-efficacy, assertive behaviour and self-esteem and how these factors related to career success in the military environment. Furthermore, Ditsela and Van Dyk (2013) provide an analytical review of the job characteristics that influence the career success of soldiers. The authors discussed both objective and subjective job characteristics such as quality of the environment, job demands, role conflict, value conflict, job security and the psychological contact. Both analytical reviews provide extremely valuable information, which enhances our understanding of military career success within the South African context. Ballout (2009) however explained that it is imperative to study the factors underlying career success, from the view point of the individual. Knowing and understanding these factors are particularly important for organisations who are interested in retaining motivated and competent members. Considering the paucity of research carried out within the African context, this study aims to address this issue and fill a gap within the literature by examining the perceptions of permanent Operational Forces soldiers' with regard to the attributes and skills that contributed to their career success.

Successful candidates display skills and attributes that are suited to the specific environment. There is a clear distinction between skills and attributes. Job skills, also known as 'hard skills' are technical skills that can be learned through training and/or education to enable the performance of context-specific tasks (Brannick, Levine \& Morgeson, 2007). These might be techniques or processes (e.g. how to operate some form of machinery). On the other hand, attributes fall into the category of 'soft skills'. These can be classified as personal or interpersonal talents that cannot necessarily be measured, but they have an effect on job performance (e.g. ability to work in a team, ability to communicate and flexibility). It is important to understand that these two types of skills should not be opposing, but rather they should be complementary (Pearlman, 1997).

The results of the study will provide military organisations with key attributes and skills that make the profile of a successful Operational Forces soldier. These results will also prove useful in the recruitment and selection process to ultimately allow candidates with the highest potential for career success in the Operational Forces context to be identified for training, minimising the potential of recruiting candidates that are less likely to achieve success.

The following research questions guided the current study:

- What attributes contributed to the Operational Forces soldiers' attainment of career success?

- What skills contributed to the Operational Forces soldiers' attainment of career success?

\section{Research design Research approach and strategy}

A qualitative exploratory research approach was used to explore the perceived attributes and skills related to career success in a sample of permanent Operational Forces soldiers. Qualitative research allows for an in-depth and in-detail examination of a research problem as it is based on human experience, which can be both powerful and compelling (Babbie, 2013). This study aims to examine the perceptions of permanent Operational Forces soldiers with regard to the attributes and skills that contributed to their career success.

\section{Research method Research setting}

Qualitative questionnaires were administered to a group of Operational Forces soldiers from five different locations in South Africa. The Operational Forces are a highly exclusive,

TABLE 1: Attributes and skills related to military career success.

\begin{tabular}{lllll}
\hline Presence & Will & Character & Attitude & Cognitive \\
\hline Maturity & Calm & Reliable & Commitment & Sound judgement \\
Persistent & Hardy & Empathy & Competitive & Initiative \\
Self-confident & Adaptability & Organised & Risk taker & High intellectual ability \\
Decisiveness & Stability & - & - & Thinks practically \\
- & Perseverance & - & - & Competent in reading maps \\
- & Low anxiety & - & - & - \\
- & Functions under pressure & - & - & - \\
\hline
\end{tabular}

Source: Please see the full reference list of the article, Rawoot, l., Van Heerden, A., \& Parker, L. (2017). Operational Forces soldiers' perceptions of attributes and skills for career success. SA Journal of Industrial Psychology/SA Tydskrif vir Bedryfsielkunde, 43(0), a1440. https://doi.org/10.4102/sajip.v43i0.1440, for more information 
specialised military unit. Because of the challenge of recruiting and selecting successful Operational Forces soldiers, the researchers sought to identify what attributes and skills make up the profile of a successful Operational Forces soldier, particularly within the South African context.

\section{Entrée and establishing researcher roles}

The researchers made personal contact with each of the potential participants. The researchers have a working relationship with the organisation from which participants were sampled. The head of each of the units assisted the researchers with broadening the sample.

The researchers all participated fully in all aspects of the study. The researchers planned and conceptualised the study and facilitated the collection of data, transcription of the data as well as the thematic analysis of the data and writing of the manuscript.

\section{Research participants and sampling methods}

A non-probability, convenience sample of 98 permanent Operational Forces soldiers participated in the study. Participants were all male, between the ages of 24 and 58 (mean age 39.2 years), with varying ranks and years of experience (1-38 years). Participants were recruited from five Operational Forces locations in South Africa. The race distributions of the sample were as follows: 49 black, 13 white, 4 coloured and 31 participants who chose to omit their race.

\section{Data collection methods}

A qualitative survey was used to collect the data for the study. While the term 'qualitative survey' is very rarely used in general research methodology, Fink (2003) recommends the qualitative survey as a useful tool for gathering facts about people's beliefs, feelings and experiences. A welldesigned qualitative survey allows the participants the freedom to express their views in response to a question without any influence from the researcher. A survey, therefore, reduces researcher/interviewer bias because there are no verbal or visual clues that could influence the participant's answer (Babbie, 2013).

The use of this method was particularly suited to the sample under investigation, as surveys are an effective tool for collecting data on sensitive or secretive topics (Patten, 1998) and are more practical for Operational Forces soldiers who have busy schedules. These soldiers are rarely able to set aside lengthy periods of time for interviews because of the nature of their job. The qualitative survey, as opposed to an interview, can be completed at any time, making it more convenient (Foxcroft \& Roodt, 2009). The self-administered survey was developed specifically for the purpose of this study and included 10 questions. The questions were all aimed at gaining a better understanding of the attributes and skills related to career success from the perspective of
Operational Forces soldiers. Examples of the questions asked include:

- Please share what made you want to become an Operational Forces soldier?

- In your opinion, what attributes are important for individuals to possess in order for them to be a successful Operational Forces soldier?

- Which skills were the most useful in preparing you for your career as an Operational Forces soldier?

- What type of person should we be recruiting if we want an improved qualification rate?

\section{Data recording}

Participants recorded their answers directly on the questionnaire. The data were captured by the researchers into an electronic format. In total, approximately 100 pages of data were produced as a result of this capturing process. By transcribing the data themselves, the researchers were able to familiarise themselves with the data, an essential process when conducting qualitative research (Babbie, 2013).

\section{Strategies employed to ensure data quality and integrity}

To ensure that the research was conducted within an ethical framework (Foxcroft \& Roodt, 2009), ethical clearance was first sought and obtained from the participating organisation to ensure that the study complied with all such requirements. All possible precaution was taken to ensure that participants were comfortable and protected for the duration of the study. Participants were well informed about the nature and purpose of the study. The questionnaire was strictly confidential, and participants were informed that they did not need to include their name or any identifying information. Questionnaires and the transcriptions were stored in a locked cabinet and made available to only the researchers. No participant was coerced into participating in this study as participation was completely voluntary.

\section{Data analysis}

The data were thematically analysed by using Atlas.ti, a qualitative data analysis software programme. Using computer-aided software for the analysis procedure enables the researchers to increase the rigour as well as the manageability of the data (Babbie, 2013). The processes of analysis used by the researchers are as follows: (1) the researchers familiarised themselves with the text in order to identify themes and construct preliminary data codes; (2) using Atlas.ti, codes were identified and data were sorted into them. These ultimately formed the themes that answered the research questions, and (3) final codes and themes were thereafter confirmed and analysed accordingly. In addition to the thematic analysis conducted in Atlas.ti, the researchers conducted a manual data analysis to supplement and enhance the findings of the study. During the analysis, the specific research setting of the study and the biographical profile of the sample was taken into consideration (Babbie, 2013). 


\section{Reporting style}

The findings of the study are reported in a qualitative reporting style, presenting in-depth information and direct quotes from the transcriptions. Murphy's typology (1996) was used as a means of classification for the findings. The findings are presented within organised categories (selfconcept, personality, interests, cognitive ability and physical ability):

- What attributes contributed to the Operational Forces soldiers' attainment of career success?

- What skills contributed to the Operational Forces soldiers' attainment of career success?

\section{Findings}

The thematic analysis yielded various attributes and skills that contribute to the career success of Operational Forces soldiers. These were sorted into organised categories based on Murphy's typology (1996). The categories include self-concept, personality, interests, cognitive ability and physical ability (see Table 2). Each category will be further discussed.

\section{Self-concept}

Self-concept refers to the self-constructed beliefs that one holds about oneself and the responses of others (Oyserman, Elmore \& Smith, 2012). From the results, self-concept factors contributing to career success of Operational Forces soldiers include integrity (being honest and trustworthy), having a good work-personal life balance (managing time well), having a positive attitude, good interpersonal skills (particularly with regard to interactions with superiors), maturity, professionalism, motivation and can work in a team or in isolation. These are illustrated in the quotes below:

\footnotetext{
'You must be absolutely trustworthy - your integrity should be unquestionable.' [Participant 7; Age 31]

'Must be a matured and balanced person.' [Participant 8; Age 50]

'Without positive attitude and commitment it will be difficult to succeed in high-profile missions.' [Participant 57; Age 49]
}

'Have to have very good communications skills.' [Participant 52; Age omitted]

'Able to perform tasks in isolation and are flexible enough to perform tasks as part of a team.' [Participant 32; Age 24]

'Show professionalism in each and every operation.' [Participant 89; Age 36]

The predominant factor from this theme was, however, motivation. This is in line with international literature that says understanding what motivates people and how to effectively motivate them are key components in any successful career (Hernandez \& Johnson, 2014). Motivation can be divided into two components, intrinsic motivation, which has to do with the psychological compensation that an individual receives from the work, and extrinsic motivation, which relates to the economic rewards of the job. Within the South African Operational Forces, identifying what motivates individuals to want to be a part of this elite unit is a fundamental element in terms of both recruitment as well as retention. A great deal of literature points towards the importance of intrinsic motivation in military attrition and retention (Hernandez \& Johnson, 2014; Thomas \& Jansen, 1996; Wrzesniewski et al., 2014). Organisations rely less on micro-management and compliance, but more on judgement, commitment and self-management. Because of this, the intrinsic motivation of members is a key factor in the performance of the organisation (Thomas \& Jansen, 1996).

The study identified that participants, who were all already successful members of the Operational Forces, shared very similar motivations for wanting to be a part of this group. Overall, participants provided more intrinsic than extrinsic factors as motivation for career success. 'Money' was the only extrinsic factor that participants mentioned. However, it is important to note that participants who did mention this also provided a number of intrinsic factors that motivated them. Money alone was therefore not found to be the sole reason for participants wanting to be a part of the Operational Forces. The motivators included wanting to be the best, 'I wanted to be the best, not to be like any other soldier' [Participant 9; Age 54), the opportunity to be in a 'challenging and exciting environment' [Participant 77; Age 42),

TABLE 2: Summary of factors contributing to career success.

\begin{tabular}{llll}
\hline Self-concept & Personality & Interest & Cognitive ability \\
\hline Trustworthy & Self-discipline & Eagerness towards military career & Physical ability \\
Good time management & Open mindedness & Interest in the values and missions of the SANDF & Education level \\
Professionalism & Excitement seeking & - & Physically fit \\
Positive attitude & Focussed and goal driven & - & Medically fit \\
Integrity & - & - & Technology \\
Balance & - & - & Language and communication \\
Respect for superiors & - & - & Seaborne skills \\
Motivation & - & - & Novirborne skills \\
Maturity & - & - & Problem solving \\
Working in a team or in isolation & - & - & Leadership \\
Mental toughness & - & - & Trainable \\
Perseverance & - & - & Sound judgement \\
- & - & - & Concentrate for long \\
- & - & - & Intelligence \\
\hline
\end{tabular}


'developing lots of new skills' [Participant 9; Age 43) and 'in search of the ultimate adventure' [Participant 71; Age 30). For most participants, joining the Operational Forces was said to be a calling, 'It is in my blood, it was a calling, and not everyone got called' [Participant 94; Age 39). Because the literature points towards the importance of intrinsic factors in military attrition and retention (Hernandez \& Johnson, 2014), and participants all expressed very similar motivation for wanting to be a part of the Operational Forces, it is important for the organisation to explore new candidates' motivation for wanting to be a part of this group. A new candidate who believes that being in this career is a calling is more likely to be retained in the long run, rather than a candidate motivated by extrinsic factors such as money and benefits of the job.

\section{Personality}

According to McCrae and Costa (2008), personality refers to individual differences in characteristic patterns of thinking, feeling and behaving. Psychologists generally agree that personality can be summarised by what is commonly known as the 'Big Five'. The Big Five traits include openness, conscientiousness, extraversion, agreeableness and neuroticism, which capture the main dimensions of the individual. In terms of the military environment, specialised soldiers typically require a particular type of personality that may offend the more conventional, live-by-the-book, military types. Specialised soldiers possess a certain confidence in their capabilities and independence of character (Taillon, 2006).

Four personality factors were identified in these results. This included two conscientiousness factors (self-discipline and being focussed/goal driven) and two openness factors (open mindedness and excitement seeking). Conscientiousness (higher dependability and stronger achievement orientation) is positively related to career success because of the consistent relationship between conscientiousness and job performance (Hussain, Abbas, Shahzad \& Riphah, 2011; Judge \& Zapata, 2015). Openness as a personality factor is, however, less clear within the research regarding its relation to career success, as it is generally linked to career success in jobs that require creativity (Barrick \& Mount, 1991). In terms of the military environment, we may see the relation of openness to experience and career success when soldiers are required to find creative ways of using their skills, knowledge and abilities to address demanding, context-specific, practical problems. Members also need to be exceptionally openminded and adaptable (De Beer \& Van Heerden, 2014). No personality factors linked to neuroticism were mentioned by participants in the study. This is in line with the literature on the Big Five model that acknowledges neuroticism as being negatively related to career success (Judge et al., 1995).

'We have to select and identify individual who are disciplined and have good qualities of an operator.' [Participant 10; Age 50]

'Self-discipline without no mission or task can be completed.' [Participant 11; Age 46]
'I love the unpredictability, the changing circumstances the element of danger and uncertainty that is involved in being an operator. I love the excitement and the unique skills that you learn and master.' [Participant 33; Age 24]

\section{Interests}

'An interest is a learned affective response to an object or activity; things in which we are interested elicit positive feelings' (Schmitt, 2012, p. 39). Eagerness towards military career and an interest in the values and missions of the SANDF was pointed out as a key contributing factor to career success in the Operational Forces. Participants expressed that their own interests and values were strongly aligned to the SANDF and knowing this from the start of their careers served as an additional contributing factor to career success. Participants also expressed that 'a lack of interest in our SANDF vision and mission' [Participant 65; Age 31) would limit career success and that it is therefore crucial to ensure that new recruits know and internalise the values of the SANDF from the beginning to ensure that their interests align strongly with that of the organisations.

'These values must be embedded in the candidate's minds.' [Participant 72; Age 46]

'The values is a must and you have to know it by heart.' [Participant 99; Age 43]

\section{Cognitive ability}

Cognitive ability can be defined as 'the capacity to perform higher mental processes, such as reasoning, remembering, understanding, problem solving and decision making' (Bernstein, Penner, Clarke-Stewart \& Roy, 2011, p. 408). Cognitive abilities were identified as being crucial to career success in the Operational Forces. Specific cognitive abilities mentioned by members were decision-making, appropriate education level, technological skills and language and communication skills. Members deemed these cognitive attributes and skills imperative in order to obtain career success. They often highlighted the importance of the abovementioned skills and attributes and their link to success such as that illustrated in the following quotes:

'Academics (operator's classes/lessons), team work - you have no choice but to join the rest so as to make it.... Most important is individual intelligence.' [Participant 31; Age 26]

'... technology, literacy with good communications skills.' [Participant 46; Age 43]

Decision-making is described as the selection of tactical and strategic plans, which are frequently primed by the recognition of learned patterns. Formal instruction in decision-making techniques may improve the quality of decisions, but some aspects of successful decision-making are determined by individual dispositions (Morrison \& Fletcher, 2002). Decision-making is an important aspect in this environment as important decisions often need to be made with regard to various operations. Respondents explained the importance of decision-making in the organisation: 
'decision-making, one knows that the organisation comes first and formulated all his decisions based on the organisation demand after his own.' [Participant 12; Age 46]

Leadership is a complex construct, which consists of many components, with decision-making being one of them. Leadership appears to consist of motivational patterns and a combination of technical, conceptual and interpersonal skills, the last being the most difficult to acquire and measure (Morrison \& Fletcher, 2002). However, technical and conceptual skills needed by leaders can, to an appreciable extent, be taught. Interpersonal skills and patterns of motivation required for leadership appear to be more dependent on native abilities and are thus more difficult to teach (Morrison \& Fletcher, 2002). Leadership was deemed as being an important aspect in career success as it contributed to the overall success and condition of the group. Members also stipulated that leadership had a great impact on them as it was something to aspire to. They also saw it as a means of encouragement, which catalysed them to aspire to be better.

'...leadership also is useful cause it will be easy to have team spirit if there is good leadership.' [Participant 40; Age 50]

'leadership was the most important aspect that impacted so heavy in my life as I just wanted to prove to them that I can be like them. They way in which they believed in the teams in order to enhance the training was an example of focus on objectives.' [Participant 68; Age 52]

\section{Physical ability}

Throughout military literature, physical ability is the primary criterion for what makes a successful soldier. Results of the study showed that participants constantly referred to the physical fitness component of the job, indicating its significance in military career success.

'Physical fitness was and still is the most essential for any person thinking of a career in Operational Forces ...' [Participant 72; Age 46]

'...you must enhance fitness level for the harsh selection.' [Participant 99; Age 33]

In addition to being physically and medically fit for the job, participants believed that specific skills such as battle handling (weapon accuracy and minor tactics), airborne skills (being parachute qualified), seaborne skills (exceptional swimming abilities) and navigation skills (being able to successfully navigate using a map) all contributed to their career success. These were skills which participants felt were necessary for any individual to possess and be able to master, in order to have a successful career as an Operational Forces member.

'Recently qualified operators are lacking the basic skills.' [Participant 7; Age 31]

'They lack swimming skills.' [Participant 9; Age 43]

'Many of them are lacking the basic skills like shooting, minor tactic drills, etc. More time is needed trying to get these members to pass basic shooting, etc.' [Participant 7; Age 31]
It was noted that some of these essential skills, which are required for a successful Operational Forces career, is seriously lacking in new recruits. Further research should aim to explore ways to improve the recruitment procedures to ensure that more suitable candidates are selected.

\section{Discussion}

The aim of the study was to explore the perceptions of Operational Forces soldiers regarding the unique skills and attributes that facilitated their career success. Brannick et al. (2007) define 'job skills' as technical skills that can be learned through training and/or education to enable the performance of context-specific tasks, while 'attributes' can be classified as personal or interpersonal talents that have an effect on job performance (Pearlman, 1997). Results have confirmed previous research pertaining to the factors that contribute to career success in the specialised military context.

The findings point to the importance of attributes associated with candidates' positive self-concept of which intrinsic motivation was found to be a powerful factor. This was related to various meaningful objectives like money, ambition and status (Hernandez \& Johnson, 2014). Findings from this research study suggested that drivers of intrinsic motivation for these individuals were personal but also universal in their power to motivate. The findings were in line with the literature, which points towards the importance of intrinsic motivation in military attrition, retention and the success of the organisation as a whole (Thomas \& Jansen, 1996). In terms of personality factors, the results show four factors, two of which were conscientiousness factors (self-discipline and being focussed/goal driven) and two openness factors (open mindedness and excitement seeking). In line with previous research, these findings confirmed the consistent relationship between conscientiousness and job performance (Barrick \& Mount, 1991; Hussain et al., 2011; Judge \& Zapata, 2015). Results indicated that attributes like personal values, goals and interests aligned with the values of the military organisation. This was an additional contributing factor to career success. Gayton and Kehoe (2015) found that within the Australian Army Special Forces, successful applicants ranked attributes like being a team worker $(72 \%)$, integrity $(67 \%)$ and persistence $(50 \%)$ as the top three character strengths. This was in line with the findings of this study which indicated that members deemed character strengths such as working in a team, integrity and perseverance imperative in order to obtain career success. In terms of required skills within the Operational Forces context, cognitive abilities deemed to be important included skills such as decisionmaking, appropriate education level, technological skills and language and communication skills (Masland \& Lyons, 2015; Proyer, Annen, Eggimann, Schneider \& Ruch 2012). It was confirmed that decision-making skills and communication skills led to the development of leadership skills and attributes. This study found that leadership was viewed as a particular important aspect in career success as it contributed to the overall success and condition of the 
group motivation and commitment as well as on an individual level where Operational Forces soldiers view their seniors as mentors and symbols of what they aspire to (Zaccaro et al., 2015). Finally, and in line with previous research, the data from this research confirmed the critical importance of physical fitness as a critical skill required for success in the Operational Forces environment (Solberg et al., 2015).

\section{Conclusion}

This study has made a contribution to the broader knowledge base of attributes and skills. Over and above physical fitness, there are other contributing factors, which influence career success of Operational Forces soldiers from South Africa. The demanding Operational Forces environment comes with its own unique set of challenges and stressors that require very specific attributes and skills to ensure a successful career within this domain. This study fulfilled its overall aim of exploring the perceptions of South African Operational Forces soldiers regarding the unique attributes and skills that facilitated their career success. This was considered within a South African military organisational environment in which few studies have been conducted from a South African context, until the recent past. Results of the study were found to be in line with previous international findings adding to a broader and more culturally representative international sample. The study extends previous career success research by contributing an additional base of information regarding career success and factors that are perceived to influence it within the Operational Forces context. The research findings may help to inform decisions about approaches, practices and methodologies of the South African Operational Forces as well as international recruitment and selection processes. This can be achieved by providing insight into key characteristics to look for in identifying candidates with the highest potential of obtaining career success. The study included a very specific sample, and results of the study may therefore not be generalisable to a larger population. The attributes and skills identified in this study could be used as a foundation for creating possible quantitative surveys which could be applied on a larger scale and applied to broader settings.

\section{Acknowledgements}

This research work was supported by both the Council for Scientific and Industrial Research (CSIR) and the South African Operational Forces. The authors wish to thank the South African Operational Forces for their full cooperation in this research project. The views expressed in this article are those of the authors and do not represent an official position of the South African Operational Forces.

\section{Competing interests}

The authors declare that they have no financial or personal relationship(s) which may have inappropriately influenced them in writing this article.

\section{Authors' contributions}

I.R. was the project manager for this research study. I.R., A.V.H. and L.P. all made contributions towards the conceptualisation of the project, data collection, data analysis and writing of the manuscript.

\section{References}

Arthur, M.B., Khapova, S.N., \& Wilderdom, C.P.M. (2005). Career success in a boundary-less career world. Journal of Organisational Behaviour, 26, 177-202. https://doi.org/10.1002/job.290

Babbie. E. (2013). The practice of social research. (13th edn.). Belmont, CA: Wadsworth Cengage Learning.

Ballout, H.I. (2009). Career commitment and career success: Moderating role of selfefficacy. Career Development International, 14(7), 655-670. https://doi. org/10.1108/13620430911005708

Barrick, M.R., \& Mount, M.K. (1991). The big five personality dimensions and job performance: A meta-analysis. Personnel Psychology, 44, 1-26. https://doi. org/10.1111/j.1744-6570.1991.tb00688.x

Bernstein, D.A., Penner, L.A., Clarke-Stewart, A., \& Roy, E.J. (2011). Psychology (9th edn.). Belmont, CA: Wadsworth Cengage Learning.

Brannick, M.T, Levine, E.L. \& Morgeson, F.P. (2007). Job analysis: Methods, research, and applications for human resource management (2nd edn.). Thousand Oaks, CA: Sage.

Braun, D.E., Prusaczyk, W.K. Goforth, H.W. \& Pratt, N.C (1994) Personality profiles of U.S. Navy Sea-Air-Land (SEAL) personnel. San Diego, CA: Naval Health Research Centre.

Bullis, J.R., Boe, H.J., Asnaani, A., \& Hofmann, S.G. (2014). The benefits of being mindful: Trait mindfulness predicts less stress reactivity to suppression. Journal of Behavioural Therapy and Experim org/10.1016/j.jbtep.2013.07.006

Cacioppo, J.T., Adler, A.B., Lester, P.B., McGurk, D., Thomas, J.L., Chen, H.Y., \& Cacioppo, S. (2015). Building social resilience in soldiers: A double dissociative randomized controlled study. Journal of Personality and Social Psychology, 109(1), 90-105. https://doi.org/10.1037/pspi0000022

Christopher, G., Garber, M.B., Butler, R., \& Rauh, M.J. (2017). Relationship between functional tests and injury occurrence in male soldiers undergoing Special Force assessment and selection. Journal of Orthopaedic \& Sports Physical, 47(1), A36.

Collins, J.M. (1987). Green Berets, SEALS and Spetsnaz. Washington, DC: PergamonBrassey's.

Cornum, R., Matthews, M.D., \& Seligman, M.E. (2011). Comprehensive soldier fitness: Building resilience in a challenging institutional context. American Psychologist 66(1), 4-9. https://doi.org/10.1037/a0021420

De Beer, M., \& Van Heerden, A. (2014). Exploring the role of motivational and coping resources in a Special Forces selection process. SA Journal of Industrial Psychology, 40(1), Art. \#1165, 1-13. https://doi.org/10.4102/sajip.v40i1.1165

De Beer, M., \& Van Heerden, A. (2017). The psychological coping, learning potential and career preferences profiles of operational force military candidates. Journal of Psychology in Africa, 27(1), 33-40.

Dees, R.A., Nestler, S.T., \& Kewley, R. (2013). Whole Soldier performance appraisal to support mentoring and personnel decisions. Decision Analysis, 10(1), 82-97. https://doi.org/10.1287/deca.1120.0263

Ditsela, N., \& Van Dyk, G.A.J. (2013). Job characteristics that influence the career success of soldiers in the South African National Defence Force: An analytical review. Journal of Psychology in Africa, 23(2), 369-374.

Eskreis-Winkler, L., Shulman, E.P., Beal, S.A., \& Duckworth, A.L. (2014). The grit effect: Predicting retention in the military, the workplace, school and marriage. Frontier in Psychology, 5(36), 1-12. https://doi.org/10.3389/fpsyg.2014.00036

Fink, A. (2003). The survey handbook. Thousand Oaks, CA: Sage.

Foxcroft, C., \& Roodt, G. (2009). Introduction to psychological assessments in the South African context. (3rd edn.). Cape Town, South Africa: Oxford University Press.

Gayton, S.D., \& Kehoe, E.J. (2015). A prospective study of character strengths as predictors of selection into the Australian army special force. Military Medicine, 180(2), 151-157. https://doi.org/10.7205/MILMED-D-14-00181

Gee, D. (2007). Informed choice? Armed forces recruitment practice in the United Kingdom. Retrieved February 23, 2016, from https://www.essex.ac.uk/armedcon/ story_id/000733.pdf

Grigsby, W.W., Gorman, S., Marr, J., McLamb, J., Stewart, M., \& Schifferle, P. (2012) Integrated planning the operations process, design, and the military decision making process. Military Review, 92(4), 28-35.

Gross, J.J., \& John, O.P. (2003). Individual differences in two emotion regulation processes: Implications for, relationships, and well-being. Journal of Personality and Social Psychology, 85(2), 348-362. https://doi.org/10.1037/0022-3514.85. 2.348

Harris, L.C., \& Ogbonna, E. (2006). Approaches to career success: An exploration of surreptitious career-success strategies. Human Resource Management, 45(1), 43-65. https://doi.org/10.1002/hrm.20095

Hernandez, L.F., \& Johnson, D.K. (2014). Designing incentives for Marine Corps cyber workforce retention. Monterey, CA: Naval Postgraduate School. 
Higgins, W.J.F., Carrasco, M.D.R.D., Gunn, J.D., López, A.M., Heredia, R.G., García, G.V. et al. (2015). Calakmul: Power, perseverance, and persistence. In A. Cucina (Ed.) Archaeology and bioarchaeology of population movement among the prehispanic Archaeology and bioarchaeology of population movement am
Maya (pp. 37-50). Merida: Springer International Publishing.

Hussain, S., Abbas, M., Shahzad, K., \& Riphah, S.A.B. (2011). Personality and career choices. African Journal of Business Management, 6(6), 2255-2260.

Joint Operations University. (2011, November). The OSS model and the future SOF warrior. Retrieved September 13, 2016, from http://jsou.libguides.com/ld. php?content_id $=21954652$

Judge, T.A., Cable, D.M., Boudreau, J.W., \& Bretz, R.D. (1995). An empirical investigation of the predictors of executive career success. Personnel Psychology, 48(3), 485519. https://doi.org/10.1111/j.1744-6570.1995.tb01767.x

Judge, T.A., \& Zapata, C.P. (2015). The person-situation debate revisited: Effect of situation strength and trait activation on the validity of the Big Five personality traits in predicting job performance. Academy of Management Journal, 58(4), 1149-1179. https://doi.org/10.5465/amj.2010.0837

Kautz, T., Heckman, J.J., Diris, R., Weel, B., \& Borghans, L. (2014). Fostering and measuring skills: Improving cognitive and non-cognitive skills to promote lifetime success. (NBER Working Paper No. 20749). Cambridge, MA: National Bureau of Economic Research.

Kelly, D.R., Matthews, M.D., \& Bartone, P.T. (2014). Grit and hardiness as predictors of performance among West Point cadets. Military Psychology, 26(4), 327-342. https://doi.org/10.1037/mil0000050

Knapp, D.J., \& Keenan, A. (2004). Select 21 project criterion measures. Alexandra, VA: Human Resources Research Organization.

Koekemoer, E. (2014). An explorative study on factors influencing the career success of management employees. South African Journal of Industrial Psychology, 40(2) Art. \#1204, 1-10. https://doi.org/10.4102/sajip.v40i2.1204

Lovering, M.E., Heaton, K.J., Banderet, L.E., Neises, K., Andrews, J., \& Cohen, B.S (2015). Psychological and physical characteristics of US Marine recruits. Military Psychology, 27(5), 261-275. https://doi.org/10.1037/mil0000082

Masland, J.W., \& Lyons, G.M. (2015). Education and military leadership. Princeton, NJ: Princeton University Press.

McCrae, R.R., \& Costa, P.T. (2008). The five-factor theory of personality. In O.P. John, R.W. Robins, \& L.A. Pervin (Eds.), Handbook of personality: Theory and research (pp. 159-181, 3rd edn.). New York: Guilford Press.

Menon, S.T., \& Kotze, E. (2007). Human resource integration in the South African military: A view from the trenches. Human Resource Management, 46(1), 71-94. military: A view from the trenches. Hur
https://doi.org/10.1002/hrm.20146

Moorcroft, H.S. (2006). The relationship between experiences in the South African Special Forces and current levels of well-being and sense of coherence. Unpublished Master's thesis, University of Pretoria, Pretoria, South Africa.

Morrison, J.E., \& Fletcher, J.D., (2002). Cognitive readiness. Alexandria, VA: Institute for Defense Analysis. https://doi.org/10.1037/e431002005-001

Murphy, K.R. (Ed.). (1996). Individual differences and behavior in organizations. San Francisco, CA: Jossey-Bass.

Ng, T.W.H., Eby, L.T., Sorensen, K.L., \& Feldman, D.C. (2005). Predictors of objective and subjective career success: A meta-analysis. Personnel Psychology, 58, 367-408. https://doi.org/10.1111/j.1744-6570.2005.00515.x

Ng, T.W.H., \& Feldman, D.C. (2014). Subjective career success: A meta-analytic review. Journal of Vocational Behavior, 85(2), 169-179. https://doi.org/10.1016/j. jvb.2014.06.001

Nye, C.D., Beal, S.A., Drasgow, F., Dressel, J. D., White, L.A., \& Stark, S. (2014). Assessing the tailored adaptive personality assessment system. Urbana, IL: Drasgow Consulting Group.

Orb, A., Eisenhauer, L., \& Wynaden, D. (2004). Ethics in qualitative research. Journal of Nursing Scholarship, 33(1), 93-96. https://doi.org/10.1111/j.1547-5069.2001.00093.x
Orvis, B.R., \& Asch, B.J. (2001). Military recruiting: Trends, outlook and implications. Washington, DC: RAND, National Defense Research Institute.

Oyserman, P., Elmore, K., \& Smith, G. (2012). Self, self-concept, and identity. In M.R. Leary \& J.P. Tangney (Eds.), Handbook of self and identity (pp. 69-104, 2nd edn.). New York: Guilford Press.

Patten, M.L. (1998). Questionnaire research: A practical guide. Los Angeles, CA: Pyrezak Publishing.

Pearlman, K. (1997). Twenty-first century measures for twenty-first century work. In A. Lesgold, M.J. Feuer \& A.M Black (Eds.), Transitions in work and learning: Implications for assessment (pp. 136-179). Washington, DC: National Academy Press.

Proyer, R.T., Annen, H., Eggimann, N., Schneider, A., \& Ruch, W. (2012). Assessing the 'good life' in a military context: How does life and work-satisfaction relate to orientations to happiness and career-success among Swiss professional officers? Social Indicators Research, 106(3), 577-590. https://doi.org/10.1007/s11205-011-9823-8

Sacolick, B. (2008). Character and the Special Forces Soldier. Small Wars Journal LLC. Retrieved February 23, 2016, from http://smallwarsjournal.com/jrnl/art/ character-and-the-special-forces-soldier

Savickas, M.L. (2005). The theory and practice of career construction. In S.D. Brown \& R.T. Lent (Eds.), Career development and counseling: Putting theory and research to work (pp. 42-70). Hoboken, NJ: Wiley.

Schmitt, N. (2012). The Oxford handbook of personnel assessment and selection. New York: Oxford University Press.

Skomorovsky, A., \& Sudom, K.A. (2011). Role of hardiness in the psychological wellbeing of Canadian forces officer candidates. Military Medicine, 176, 1-7. https:// doi.org/10.7205/milmed-d-10-00325

Smith, M., \& Heinecken, L. (2014). Factors influencing military recruitment in South Africa: The voices of Cape Town high school learners. African Security Review, 23(2), 102-116. https://doi.org/10.1080/10246029.2014.902388

Solberg, P.A., Paulsen, G., Slaathaug, O.G., Skare, M., Wood, D., Huls, S., et al. (2015). Development and implementation of a new physical training concept in the Norwegian Navy Special Operations Command. The Journal of Strength \& Conditioning Research, 29, S204-S210. https://doi.org/10.1519/JSC.0000000000001085

Taillon, J.P.B. (2006). Canadian Special Operations Forces: Transforming paradigms. Canadian Military Journal, 6(4), 67-76.

The House of Commons. (2008). Recruiting and retaining Armed Forces personnel. London: House of Commons Defence Committee.

Thomas, K., \& Jansen, E. (1996). Intrinsic motivation in the military: Models and strategic importance. Monterey, CA: Naval Postgraduate School.

Tilman, T., Ravizza, K., \& Statler, T. (2011). Clear your mind to clear the way; managing the moment. Engineer, 41(1), 32-35.

U.S. Department of the Army. (1994). Field Manual No. 22-51. Retrieved March 16, 2016, from http://webapp1.dlib.indiana.edu/virtual_disk_library/index. cgi/4931363/FID2617/DATA/operationalmed/manuals/fm22-51/02fm2251.html

Van Dyk, G., \& Ditsela, N. (2013). Personality factors explaining career success for soldiers: An analytical review. Journal of Psychology in Africa, 23(4), 679-683.

Visser, D. (2002). British influence on military training and education in South Africa: The case of the South African Military Academy and its predecessors. South Africa Historical Journal, 46(1), 63-82. https://doi.org/10.1080/02582470208671419

Wrzesniewski, A., Schwartz, B., Cong, X., Kane, M., Omar, A., \& Kolditz, T. (2014). Multiple types of motives don't multiply the motivation of West Point cadets. Proceedings of the National Academy of Sciences, 111(30), 10990-10995. https:// doi.org/10.1073/pnas.1405298111

Zaccaro, S.J., Connelly, S., Repchick, K.M., Daza, A.I., Young, M.C., Kilcullen, R.N., et al (2015). The influence of higher order cognitive capacities on leader organizational continuance and retention: The mediating role of developmental experiences. The Leadership Quarterly, 26(3), 342-358. https://doi.org/10.1016/j.leaqua.2015. 03.007 a 